\title{
Evaluation of the Effects of Magnesium Sulfate on Prevention of Post-dural-Puncture Headache in Elective Cesarean in Kamali Hospital
}

\author{
Banafsheh Mashak ${ }^{1}$, Seyyed Mohsen Pouryaghobi ${ }^{1}$, Mehdi Rezaee ${ }^{2}$, Samira Saee Rad $^{3}$, Mina Ataei ${ }^{4^{*}}$, \\ Aida Borzabadi ${ }^{5}$
}

\author{
${ }^{1}$ Assistant Professor of Anesthesioligy, Alborz University of Medical Sciences, Karaj, IRAN \\ ${ }^{2}$ Department of Anesthesioligy, Alborz University of Medical Sciences, Karaj, IRAN \\ ${ }^{3}$ Medical Geneticist, Saee rad genetic laboratory, Karaj, Alborz, IRAN \\ ${ }^{4}$ Assistant Professor, Infertility Fellowship, Obstetrics and Gynecology, Social Determinants of Health Research Center, Alborz University of Medical Sciences, Karaj, \\ IRAN \\ ${ }^{5}$ Student Research Committee, Alborz University of Medical Science, Karaj, IRAN \\ ${ }^{*}$ Corresponding Author: Ataee.mina@yahoo.com
}

Citation: Mashak B, Pouryaghobi SM, Rezaee M, Rad SS, Ataei M, Borzabadi A. Evaluation of the Effects of Magnesium Sulfate on Prevention of Post-dural-Puncture Headache in Elective Cesarean in Kamali Hospital. Electron J Gen Med. 2020;17(3):em199. https://doi.org/10.29333/ejgm/7847

\section{ARTICLE INFO}

Received: 18 Sep. 2019

Accepted: 30 Dec. 2019

\begin{abstract}
Introduction: One of the most common complications of spinal anesthesia in elective cesarean is a headache, known commonly as post-dural-puncture headache (PDPH). Various methods are mainly recommended such as resting and the use of non-opioid analgesics, caffeine, and codeine, but none of them has been fully effective in its treatment. Hence, this study was conducted to evaluate the effect of magnesium sulfate on the prevention of postdural-puncture headache in the elective cesarean.

Method: a total of 68 patients candidate for elective cesarean and admitted to Kamali Hospital were selected using convenient sampling and they were randomly divided into two groups. One group received magnesium and other group received saline. Subjects of case group received magnesium at the dose of $50 \mathrm{mg} / \mathrm{kg}$ as bolus and the subjects of control group received normal saline at the same dose as bolus. The incidence of headache and its severity 12, 24, 36, 48, 60 and 72 hours after surgery were measured in both case and control groups.

Results: The mean age of patients in the magnesium sulfate group was 27.94 years with a standard deviation of 5.18 and the mean age of patients in the normal saline group was 29.35 years with a standard deviation of 5.97 . The mean body mass index (BMI) in the magnesium sulfate group was 26.34 with a standard deviation of 4.03 and the mean body mass index (BMI) in the normal saline group was 27.15 with a standard deviation of 2.47. Postdural-puncture headache severity was lower in the case group than that in the control group at all times $(P<0.05)$.

Conclusion: The results of this study revealed that intravenous administration of magnesium sulfate before elective cesarean in patients undergoing spinal anesthesia significantly decreases the severity of post-duralpuncture headache (PDPH).
\end{abstract}

Keywords: cesarean, spinal anesthesia, PDPH, magnesium sulfate

\section{INTRODUCTION}

Spinal anesthesia is considered as an anesthesia method in outpatient surgeries and it is used highly in many surgeries daily. Spinal anesthesia is done easily and it has fast effects and controls the pain as muscles are loose in surgery. However, it is followed by consequences. Two major complications of anesthesia are headache and low back pain. Post-duralpuncture headache is a common problem among young women candidate for cesarean, while the use of needles with little diameters has reduced its prevalence (1). One of the most common complications following spinal injection in elective cesarean is headache, referred as post-dural puncture headache (PDPH). Brain and spinal cord are surrounded by the
CSF and this kind of injection can cause a small leakage of cerebrospinal fluid, which this level of leakage is not risky. However, when the leakage to dural space is high, it will reduce the pressure of the fluid around the brain and finally it will cause headache $(2,3)$. Generally, symptoms of the complication emerge few hours after the dural puncture and last up to 7 days later (4-6). Risk factors for this type of headache include immediate discontinuation of caffeine using, history of previous headaches, dehydration, age, size of spinal needle diameter, and the number of dural punctures and history of previous headache following spinal injection (5). Due to the shortened hospitalization of women after cesarean section, it might occur after the discharge of mothers or it might be a cause for delay in discharge of women from the hospital (6-9). 
Any dural leakage can lead to PDPH and this headache can be spontaneous or due to medical interventions. This headache can occur up to 24 hours after spinal. The rate of this headache is highest among people aged 18-30 years and lowest among children younger than 13 and people older than 60 years $(10,11)$. Its rate is also more in people with low BMI than that in obese people. Rest, treatment with fluid, caffeine, synthetic form of adrenocorticotropic, sumatriptan, injection of Dextran and saline $9 \%$ in spinal space, blood patch and morphine injection are among the treatments investigated (1215).

Magnesium is the second intracellular cation in terms of rate and it is required for activity of most of the enzyme systems. It also plays a major role in the neuro-chemical transmission muscle stimulation $(16,17)$. Magnesium sulfate reduces muscle contraction and blocks peripheral neuromuscular transmission by reducing the release of acetylcholine at the neuromuscular junctions. It also has analgesic effect by blocking NMDA receptors (18-22). The positive effect of the intravenous magnesium sulfate in reducing migraine headaches has been proven in several studies and it has been shown that unlike other drugs prohibited during pregnancy, it is an appropriate drug $(23,24)$. CACNA1A is one of the known genes in the molecular pathway of magnesium sulfate. It is the first gene known in familial migraine (25-28). Given the incidence of mental and psychological problems as well as the increased hospital costs in patients with this complication and the lack of definite prevention methods for these types of headaches and the results of previous studies on the effect of magnesium sulfate on migraine headache treatment, the present study was conducted with the aim of evaluating the effect of magnesium sulfate on the prevention of post-dural-puncture headache in elective cesarean section surgery in Kamali Hospital (29-32).

\section{METHODOLOGY}

The present study was conducted in vitro. After obtaining the consent of the subjects and giving adequate information for patients, 68 candidates candidate for elective cesarean section were selected using convenient sampling method and were randomly divided into two groups. Exclusion criteria included known allergy to one of the drugs studied, severe kidney, liver, and heart failure, severe obesity BMI> 35, neuromuscular diseases, lumbar disc disease, history of neuropathy, use of opioid or painkiller 3 days before study, consumption of calcium channel blockers, problem in spinal block and spinal anesthesia more than two times in preoperation visit. Subjects of case group received magnesium at dose of $50 \mathrm{mg} / \mathrm{kg}$ as bolus and the subjects of the control group received normal saline at same dose as bolus. The incidence of headache and its severity 12 hours, 24 hours, 36 hours, 48 hours, 60 hours and 72 hours after surgery were
Table 1. Frequency of VAS score at hour 12 in the magnesium sulfate group based on age

\begin{tabular}{cccc}
\hline score & $\mathbf{N ~ ( \% )}$ & Age mean (SD) & P value \\
\hline 0 & $(64.7 \%) 22$ & $(5.02) 27.82$ & \\
\hline 2 & $(8.8 \%) 3$ & $(7.09) 26.33$ & \\
\cline { 1 - 3 } 3 & $(8.8 \%) 3$ & $(2.89) 32.67$ & \multirow{2}{*}{0.687} \\
\cline { 1 - 3 } 4 & $(5.9 \%) 2$ & $(7.07) 29.00$ & \\
\cline { 1 - 3 } 5 & $(8.8 \%) 3$ & $(6.51) 26.67$ & \\
\hline 7 & $(2.9 \%) 1$ & $(-) 23.00$ & \\
\hline
\end{tabular}

Table 2. Frequency of VAS score at hour 12 in the magnesium sulfate group based on BMI

\begin{tabular}{cccc}
\hline score & $\mathbf{N}(\%)$ & BMI mean (SD) & P value \\
\hline 0 & $(64.7 \%) 22$ & $(3.80) 25.55$ & \\
\cline { 1 - 3 } 2 & $(8.8 \%) 3$ & $(7.10) 27.20$ & \\
\cline { 1 - 3 } 3 & $(8.8 \%) 3$ & $(3.03) 25.50$ & \\
\cline { 1 - 3 } 4 & $(5.9 \%) 2$ & $(6.08) 28.60$ & \\
\cline { 1 - 3 } 5 & $(8.8 \%) 3$ & $(1.42) 30.07$ & \\
\hline 7 & $(2.9 \%) 1$ & $(-) 28.10$ & \\
\hline
\end{tabular}

measured in both case and control groups. Required information will be collected according to project objectives by using a questionnaire that includes demographic information and recording events related to the project. Pain ruler will be used to measure pain severity. In order to determine the severity of pain in people, VAS method is commonly used. For this purpose, the individual is asked to specify the severity of pain in a part of the affected body by selecting a number between 1 and 10 or selecting one of the options of no pain, mild pain, average pain, severe pain, the most severe pain. Chisquare and Wilcoxon tests with a significance level of less than 0.05 are used for data analysis. Statistical analysis is performed using SPSS 22 software.

\section{RESULTS}

The VAS score at the end of 12 hours in the magnesium sulfate group based on age (Table 1 ) showed that there was no significant difference in the chi-square test ( $P$ value $=0.687$ ).

VAS score at hour 12 in the magnesium sulfate group based on BMI (Table 2) showed that there was no significant difference in the chi-square test ( $P$ value 0.469 ).

VAS score at hour 12 in the magnesium sulfate group based on education level (Table 3 ) showed that there was no significant difference in the chi-square test ( $P$ value $=0.111$ ).

Then, normal saline group was examined. VAS score at hour 12 based age in Table 4 showed that there was no significant difference in chi-square test ( $P$ value $=0.622$ ).

Table 3. Frequency of VAS score at hour 12 in the magnesium sulfate group based on education level

\begin{tabular}{|c|c|c|c|c|c|c|}
\hline score & $\mathbf{N}(\%)$ & illiterate & Below diploma & diploma & academic & P value \\
\hline 0 & $(64.7 \%) 22$ & $(4.5 \%) 1$ & $(45.5 \%) 10$ & (45.5\%) 10 & $(4.5 \%) 1$ & \multirow{6}{*}{0.111} \\
\hline 2 & $(8.8 \%) 3$ & $(0 \%) 0$ & $(100 \%) 3$ & $(0 \%) 0$ & $(0 \%) 0$ & \\
\hline 3 & $(8.8 \%) 3$ & $(66.7 \%) 2$ & $(33.3 \%) 1$ & $(0 \%) 0$ & $(0 \%) 0$ & \\
\hline 4 & $(5.9 \%) 2$ & $(0 \%) 0$ & $(0 \%) 0$ & $(100 \%) 2$ & $(0 \%) 0$ & \\
\hline 5 & $(8.8 \%) 3$ & $(0 \%) 0$ & $(33.3 \%) 1$ & $(66.7 \%) 2$ & $(0 \%) 0$ & \\
\hline 7 & $(2.9 \%) 1$ & $(0 \%) 0$ & $(100 \%) 1$ & $(0 \%) 0$ & $(0 \%) 0$ & \\
\hline
\end{tabular}


Table 4. Frequency of VAS score at hour 12 in normal saline group based on age

\begin{tabular}{cccc}
\hline score & $\mathbf{N}(\%)$ & Age mean (SD) & P value \\
\hline 0 & $(14.7 \%) 5$ & $(6.69) 30.20$ & \\
\cline { 1 - 3 } 1 & $(2.9 \%) 1$ & $(-) 37.00$ & \\
\cline { 1 - 3 } 2 & $(17.6 \%) 6$ & $(2.88) 31.50$ & \\
\cline { 1 - 3 } 3 & $(35.3 \%) 12$ & $(5.98) 27.92$ & \\
\cline { 1 - 3 } 4 & $(29.4 \%) 10$ & $(7.04) 28.60$ & \\
\hline
\end{tabular}

Table 5. Frequency of VAS score at hour 12 in normal saline group based on BMI

\begin{tabular}{cccc}
\hline score & $\mathbf{N}(\%)$ & BMI mean (SD) & P value \\
\hline 0 & $(14.7 \%) 5$ & $(1.29) 26.20$ & \\
\cline { 1 - 3 } 1 & $(2.9 \%) 1$ & $(-) 26.30$ & \\
\cline { 1 - 3 } 2 & $(17.6 \%) 6$ & $(2.23) 26.52$ & \multirow{2}{*}{0.810} \\
\cline { 1 - 3 } 3 & $(35.3 \%) 12$ & $(3.12) 27.65$ & \\
\cline { 1 - 3 } 4 & $(29.4 \%) 10$ & $(2.40) 27.51$ & \\
\hline
\end{tabular}

Table 7. Comparison of mean age and BMI in two groups

\begin{tabular}{cccc}
\hline \multicolumn{4}{c}{ Mean (SD) } \\
\hline Variable & $\begin{array}{c}\text { Magnesium } \\
\text { sulfate group }\end{array}$ & $\begin{array}{c}\text { Normal saline } \\
\text { group }\end{array}$ & P value \\
\hline age & (5.18) 27.94 & (5.97) 29.35 & 0.285 \\
\hline BMI & (4.03) 26.34 & $(2.47) 27.15$ & 0.289 \\
\hline
\end{tabular}

Table 8. Comparison of patients' education level in two groups

\begin{tabular}{cccc}
\hline \multicolumn{3}{c}{$\mathbf{N}(\%)$} \\
Variable & $\begin{array}{c}\text { Magnesium sulfate } \\
\text { group }\end{array}$ & $\begin{array}{c}\text { Normal saline } \\
\text { group }\end{array}$ & P value \\
\hline illiterate & $(8.8 \%) 3$ & $(0 \%) 0$ & \\
\cline { 1 - 3 } Below diploma & $(47.1 \%) 16$ & $(41.2 \%) 14$ & \multirow{2}{*}{0.135} \\
\cline { 1 - 3 } diploma & $(41.2 \%) 14$ & $(55.9 \%) 19$ & \\
\cline { 1 - 3 } Academic & $(2.9 \%) 1$ & $(2.9 \%) 1$ & \\
\cline { 1 - 3 } & & &
\end{tabular}

Table 9. Comparison of mean VAS scores between the two groups at different times

\begin{tabular}{cccc}
\hline \multicolumn{4}{c}{ Mean (SD) } \\
\hline Mean score & $\begin{array}{c}\text { Magnesium } \\
\text { sulfate group }\end{array}$ & $\begin{array}{c}\text { Normal saline } \\
\text { group }\end{array}$ & P value \\
\hline Hour 12 & $(2.02) 1.32$ & $(1.34) 2.61$ & 0.004 \\
\hline Hour 24 & $(1.88) 1.17$ & $(1.32) 2.58$ & 0.002 \\
\hline Hour 36 & $(1.35) 0.55$ & $(1.66) 2.11$ & 0.002 \\
\hline Hour 48 & $(0.78) 0.23$ & $(1.64) 1.97$ & 0.000 \\
\hline Hour 60 & $(0.51) 0.08$ & $(1.71) 1.73$ & 0.000 \\
\hline Hour 72 & $(0.17) 0.02$ & $(1.71) 1.73$ & 0.000 \\
\hline
\end{tabular}

VAS score at hour 12 in the normal saline group according to BMI (Table 5) showed that there was no significant difference in the chi-square test ( $P$ value $=0.810$ ).

VAS score at hour 12 in the normal saline group based on education level (Table 6) showed that there was no significant difference in the chi-square test $(P$ value $=0.531$ ).
Then, age and body mass index of patients were compared in two groups (Table 7). Paired t- test showed no significant difference between them.

Then, the education level of the patients in the two groups was compared (Table 8). Wilcoxon test showed no significant difference between them.

Then, the mean VAS scores of patients were compared at hours 12, 24, 36, 48, 60 and 72 after surgery in the two groups (Table 9). Wilcoxon test showed a significant difference between the two groups in this regard ( $P$ value $<0.05$ ).

\section{DISCUSSION}

The results of the present study showed that the infusion of magnesium sulfate in patients undergoing cesarean section with spinal anesthesia reduced the incidence and severity of the headache (33). However, the mechanism of action of this effect is not known. However, it seems that interference with calcium channels and NMDA receptors to play an important role in this analgesic effect $(34,35)$. Studies have shown that calcium channel blockers increase opioids analgesics in cancer patients treated with morphine (36). As the entry of calcium into cell releases neurotransmitters and other pain-causing cases, the analgesic effect of calcium channel blockers can be due to increased pain threshold due to interference with the entry of calcium into cell $(37,38)$.

In addition, NMDA, which is an amino acid receptor and responsible for the transmission of stimuli through synapses and the junction of stimulating amino acids, such as glutamate and weakening molecules such as ketamine and magnesium, it can bind to an ion channel permeable to potassium and calcium. Magnesium inhibits the voltage-dependent flows through this receptor (39).

Accordingly, magnesium can have a preventive effect on pain before the onset of stimulation induced by surgery. Preventive analgesia can be useful for patient by preventing the formation of the central sensitization process or what occurs as a result of incision or inflammation or both of them. Many studies have shown that the need for analgesic drugs decreases with the administration of magnesium. The results of this study are similar to those of previous studies. However, most studies have focused on the effectiveness of magnesium in general anesthesia and few studies have been conducted to investigate its effect during spinal anesthesia.

Davoudi et al. (2012) carried out a research to investigate the effect of magnesium sulfate on the prevention of postoperative pain following spinal anesthesia in patients undergoing a cesarean section. In this research, 68 patients undergoing elective cesarean section were divided into two equal groups and one group received intravenous magnesium sulfate at a dose of $50 \mathrm{mg} / \mathrm{kg}$ as bolus and $10 \mathrm{mg} / \mathrm{kg}$ as a continuous infusion during surgery and the control group received normal saline at the same dose. The results revealed

Table 6. Frequency of VAS score at hour12 in normal saline group based on education level

\begin{tabular}{ccccccc}
\hline score & $\mathbf{N}(\%)$ & illiterate & Below diploma & diploma & academic & P value \\
\hline 0 & $(14.7 \%) 5$ & $(0 \%) 0$ & $(80 \%) 4$ & $(20 \%) 1$ & $(0 \%) 0$ & $(0 \%) 0$ \\
\hline 1 & $(2.9 \%) 1$ & $(0 \%) 0$ & $(0 \%) 0$ & $(100 \%) 1$ & $(0 \%) 0$ \\
\hline 2 & $(17.6 \%) 6$ & $(0 \%) 0$ & $(50 \%) 3$ & $(50 \%) 3$ & 0.531 \\
\hline 3 & $(35.3 \%) 12$ & $(0 \%) 0$ & $(33.3 \%) 4$ & $(66.7 \%) 8$ & $(0 \%) 0$ \\
\hline 4 & $(29.4 \%) 10$ & $(0 \%) 0$ & $(30 \%) 3$ & $(60 \%) 6$ & $(10 \%) 1$ \\
\hline
\end{tabular}


that intravenous injection of magnesium sulfate during cesarean section in patients undergoing spinal anesthesia reduced postoperative analgesic consumption and relieved postoperative pain (41).

The research conducted by Mavuromatti and Wolf also emphasized that magnesium sulfate as bolus and infusion reduces the need for analgesics and anesthesia drugs during surgery and improves the postoperative analgesia $(7,12)$.

In another study conducted by Howang et al (2010), results showed that pain severity decreased following the administration of magnesium sulfate in patients undergoing spinal anesthesia. In this study, the severity of pain was higher in the magnesium-receiving group than that of the control group 4, 24, and 48 hours after the surgery $(13,42)$. In the present study, the severity of pain was significantly lower in the magnesium sulfate group than that in the control group at all times. However, some studies suggest that magnesium administration near the surgery had little effect on the postoperative pain, while these studies have used low sample size $(5,6)$. Kotler et al $(2005)$ also conducted a study to compare magnesium of CSF fluid and plasma in patients who had postdural-puncture headache and the patients without headache (43). The results of the study revealed no significant difference between CSF and plasma magnesium levels of the two groups (14). However, the results of most studies in this area confirm the effectiveness of magnesium sulfate in preventing and reducing the severity of pain after spinal anesthesia.

\section{CONCLUSION}

The results of this study showed that intravenous administration of magnesium sulfate before elective cesarean section in patients undergoing spinal anesthesia significantly decreases the severity of post-dural-puncture headache (PDPH). Conducting a research with a larger sample size and evaluating the effectiveness of magnesium sulfate on other complications after cesarean section with spinal anesthesia such as shivering, itching, hot flushes, and nausea and vomiting in patients and investigating the rate of complications of magnesium sulfate administration in this group can confirm and complete our research results on the selection of this drug in preventing consequences of spinal anesthesia.

\section{ACKNOWLEDGEMENT}

Researcher appreciated Clinical Research Development Center of Kamali Hospital in Alborz University of Medical Sciences.

\section{REFERENCES}

1. Ryu JH, Sohn IS, Do SH. Controlled hypotension for middle ear surgery: A comparison between remifentanil and magnesium sulfate. $\mathrm{Br} J$ Anaesth 2009;103(4):490-5. https://doi.org/10.1093/bja/aep229 PMid:19687032

2. James MF. Clinical use of magnesium infusions in anesthesia. Anesth Analg 1992;74:129-36. https://doi.org/ 10.1213/00000539-199201000-00021 PMid:1734773
3. Wildev-Smith O, Hoffman A, Borgeat A, Rifat K. Fentanyl or magnesium analgesic supplementation of analgesic requirement. Anesthesiology 1992;77:208. https://doi.org/ 10.1097/00000542-199209001-00208 PMid:1632534

4. Miller RD. Miller's Anesthesia text book. 7th ed. Vol 2. New York: Churchill Livingstone, 2010:2757-9.

5. Bhatia A, Kashyap L, Pawar DK, Trikha A. Effect of intra operative magnesium infusion on perioperative analgesia in open choleoystectomy. J Clin Anesth 2004;16(4):262-5. https://doi.org/10.1016/j.jclinane.2003.08.012 PMid:15261316

6. Dubé L, Granry JC. The therapeutic use of magnesium in anesthesiology, intensive care and emergency medicine: a review. Can J Anaesth 2003; 50(7):732-46. https://doi.org/ 10.1007/BF03018719 PMid:12944451

7. Woolf CJ, Thompson SWN. The introduction and maintenance of central sensitization is dependent on $\mathrm{N}$ methyl D-aspartic acid receptor activation: implications for the treatment of post-injury pain and hypersensitivity states. Pain 1991;44:293-9. https://doi.org/10.1016/03043959(91)90100-C

8. Seyhan TO, Tugrul M, Sungur MO, Kayacan S, Telci L, Pembeci $K$, et al. Effects of three different dose of magnesium on propofol requirements, haemodynamic variable and post oprative pain relief in gynaecological surgery. Br J Anaesth 2006;96(2):247-52. https://doi.org/ 10.1093/bja/aei291 PMid:16311277

9. James MF. Magnesium an emeging drug in anaesthesia. $\mathrm{Br}$ J Anaesth 2009;103:465-7. https://doi.org/10.1093/ bja/aep242 PMid:19749114

10. Cizmecip, Ozkose Z. Magnesium sulfate as an adjuvant to total intravenous anesthesia in septorhinoplasty. Anesthetic Plast Surg 2007;31(2):167-73. https://doi.org/ 10.1007/s00266-006-0194-5 PMid:17437152

11. Davoudi M, Tahmasebi R, Zolhavareih SM. Evaluation of the Effect of Intravenous Magnesium Sulfate on Postoperative Pain after Cesarean Section under Spinal Anesthesia. Sci J Hamadan Univ Med Sci 2013;19(4):20-6.

12. Mavrommati PD, Gubopoulou ZT. The perioperative infusion of low doses of magnesium sulfate reduces analgesic requirements in patients undergoing abdominal hernioplasty. Sci Direct 2004;3-4:81-7. https://doi.org/ 10.1016/j.acpain.2004.01.002

13. Hwang JY, Na HS, Jeon YT, Ro YJ, Kim CS, Do SH. Infusion of magnesium sulfate during spinal anesthesia improves postoperative analgesia. Br J Anaesth 2010;104(1):89-93. https://doi.org/10.1093/bja/aep334 PMid:19933175

14. Ryo JH, Kong MH, Park KS, Do SH. Effect of magnesium sulfate on intraoperative anesthetic requirements and postoperative analgesia in gynaecology patients receiving total intravenous anaesthesia. $\mathrm{Br} \mathrm{J}$ Anaesth 2008;100(3):397-403. https://doi.org/10.1093/bja/aem407 PMid:18276652

15. Yadollahi P, Khalajinia Z, Khormaei F. Cultural differences in perception of labor pain without considering to painless technique. Journal of Advanced Pharmacy Education \& Research, 2018;8(S2):9-14.

16. Yadollahi P, Taghizdeh Z, Ebadi A. A comprehensive description of delivery pain using a qualitative approach. Journal of Advanced Pharmacy Education \& Research, 2018;8(S2):59-63. 
17. Khorasani Baghini F, Khosravani M, Amiri A. Evaluation of the effect of the provided training in delivery preparation classes on awareness and attitude of pregnant mothers toward delivery type in Razi Hospital of Saravan. Revista Latinoamericana de Hipertension, 2018;13(6):534-7.

18. Khorasani Baghini F, Khosravani M, Amiri A. Evaluation of the effect of the provided training in delivery preparation classes on awareness and attitude of pregnant mothers toward delivery type in Razi Hospital of Saravan, Revista Latinoamericana de Hipertensión. 2018;13(6). Available at: http://saber.ucv.ve/ojs/index.php/rev_lh/article/view/159 49

19. Hashemi SB, Amirfakhraei A, Mosallanezhad M, Amiri A. The effect of education on anxiety and self-efficacy in mothers of 1-3-year-old children under cochlear implant surgery, 2018: a randomized controlled clinical trial, Revista Latinoamericana de Hipertensión. 2019;14(1). Available at: http://saber.ucv.ve/ojs/index.php/rev_lh/article/view/161 70

20. Rakhshan M, Rostami K, Setoodegan E, Eslami J. The relationship between leadership style and time management in senior and middle nursing managers, Revista Latinoamericana de Hipertensión. 2019;14(1). Available at: http://saber.ucv.ve/ojs/index.php/rev_lh/ article/view/16173

21. Rostami K, Sharif F, Zarshenas L, Ebadi A, Farbood A. Design and Psychometrics of Measurement Tool of Health Needs in Patients with Chronic Back Ache, Revista Latinoamericana de Hipertensión. 2018;13(3). Available at: http://www.revhipertension.com/index_sumario_3_2018. html

22. Rostami K, Zadeh SH, Rakhshan M. Chronic pain: a concept analysis. Electronic Journal of General Medicine. 2019;16(2):em130. https://doi.org/10.29333/ejgm/94098

23. Bazrafcan L, Amini M. Using CRISIS model for designing master in medical education at Shiraz University of Medical Sciences, Medical Teacher. 2019. https://doi.org/10.1080/ 0142159X.2018.1562540 PMid:30736706

24. Bazrafcan L, Kojuri J, Amini M. Using SPICES educational strategy for undergraduate curricular reform at Shiraz Medical School, Medical Teacher. 2019. https://doi.org/ 10.1080/0142159X.2019.1582759 PMid:30922163

25. Bazrafkan I, Kalyani MN. Nursing Students' Experiences of Clinical Education: A Qualitative Study. Invest. Educ. Enferm. 2018;36(2):e04. https://doi.org/10.17533/ udea.iee.v36n3a04

26. Jaafari F, Delavari S, Bazrafkan L. Evaluation of the geriatric curriculum implemented at Shiraz University of Medical Sciences, Iran, since 2017: A qualitative study [version 1; peer review: 1 approved with reservations]. F1000Research 2019;8:417. https://doi.org/10.12688/f1000research. 16040.1

27. Eslami J, Baghini FK, Moazamfard M. The Effect of Music on the Stress Severity among the Staff of Surgery Rooms. International Journal of Pharmaceutical Research;11(2):838-43. Available at: http://ijpronline.com/ ViewArticleDetail.aspx?ID=7339

28. Rezapour-Nasrabad R. Application of Transitional Care Model in Patients with Chronic Heart Disease: A CaseControlled Intervention Study, Revista Latinoamericana de Hipertensión. 2018;13(3). Available at: http://www. revhipertension.com/index_sumario_3_2018.html
29. Rezapour-Nasrabad R. Transitional care model: managing the experience of hospital at home, Electronic Journal of General Medicine, 2018;15(5):em73. https://doi.org/ 10.29333/ejgm/93445

30. Amirfakhraei A, Hedayati M, Pirmoradi M. Coping Styles with psychological pressures in students of Iran University of medical sciences, International Journal of Pharmaceutical Research, January- March 2019;11(1):5347. https://doi.org/10.31838/ijpr/2019.11.01.071

31. Pirmoradi M, Foroghinejad N, Bedmeshki FA. The relationship between job satisfaction and social support for employees with chronic fatigue. Ann Trop Med Public Health 2017;10:1681-5. https://doi.org/10.4103/ATMPH. ATMPH_582_17

32. Pirmoradi M, Ghayoomi R, Foroghinejad N, Bedmeshki FA. The relationship between stressful life events with chronic fatigue in employees of Ahvaz water and Sewage Company, Annals of Tropical Medicine and Public Health-Special Issue Apr 2018;13:SX735-18. Available at: http://www. atmph-specialissues.org/

33. Pirmoradi MR, Poya FS, Rad MT, Veisy F, Gheitarani B, Davoodi R, Ghahari S. Comparison of Anxiety, Depression and Stress and Emotional Self-Regulation in Normal and Divorced Women. International Journal of Tropical Medicine, 2016;11:159-64. https://doi.org/10.3923/ ijtmed.2016.159.164

34. Bazrafkan L, Yousefy A, Amini M, Yamani N. The journey of thesis supervisors from novice to expert: a grounded theory study. BMC medical education. 2019 Dec;19(1):1-2. https://doi.org/10.1186/s12909-019-1739-z PMid:31438935 PMCid:PMC6704648

35. Bijani M, Ghodsbin F, Javanmardi Fard S, Shirazi F, Sharif F, Tehranineshat $B, A n$ evaluation of adherence to ethical codes among nurses and nursing students, J Med Ethics Hist Med. 2017 Jul 5;10:6. Available at: https://www.ncbi. nlm.nih.gov/pmc/articles/PMC5746660/

36. Torabizadeh C, Ghodsbin F, Javanmardifard S, Shirazi F, Amirkhani M, Bijani M. The Barriers and Challenges of Applying New Strategies in the Clinical Evaluation of Nursing Students from the Viewpoints of Clinical Teachers, Iran J Nurs Midwifery Res. 2018 Jul-Aug;23(4):305-10. https://doi.org/10.4103/ijnmr.IJNMR_17_17

PMid:30034492 PMCid:PMC6034533

37. Bijani M, Rostami K, Momennasab M, Yektatalab S, Evaluating the Effectiveness of a Continuing Education Program for Prevention of Occupational Exposure to Needle Stick Injuries in Nursing Staff Based on Kirkpatrick's Model, J Natl Med Assoc. 2018 Oct;110(5):459-63. https://doi.org/10.1016/j.jnma.2017.11.002 PMid:30129513

38. Torabizadeh C, Mahnazrakhshan, Zhilafreidooni, Njimehbeygi, Bijani M. Professional Capability in Nursing, International Journal of Pharmaceutical Research, January- March 2019;11(1):556-66. https://doi.org/ 10.31838/ijpr/2019.11.01.075

39. Bijani M, Haghshenas A, Ghasemi A. Evaluation of the Effect of Education Based on Health Belief Model on Self-Therapy and Self-medication in Students at Fasa Medical Sciences Dormitories, International Journal of Pharmaceutical Research, Jan-Mar 2019;11(3). https://doi.org/10.31838/ ijpr/2019.11.01.124 
40. Bijani M, Khaleghi AA, Hatami M, Najafi H, Haghshenas A. A study of the consistency between hypertension medications prescribed by general practitioners and 2018 ESC/ESH guidelines for the management of hypertension, Revista Latinoamericana de Hipertensión. 2019;14(1). Available at: http://saber.ucv.ve/ojs/index.php/rev_lh/ article/view/16174

41. Bijani M, Tehranineshat B, Torabizadeh C., Nurses', nursing students', and nursing instructors' perceptions of professional values: A comparative study, Nurs Ethics. 2019 May;26(3):870-83. https://doi.org/10.1177/0969733017727 153 PMid:28905676
42. Bijani M, Ghasemi A, Karimi S, Freidooni Z, Beygi N. The Role of Educational Intervention Based on the Health Belief Model in Colorectal Cancer Screening of Teachers in Fasa. Journal of Computational and Theoretical Nanoscience. 2019;16(7):2954-2958(5). https://doi.org/10.1166/jctn. 2019.8201

43. Bijani M, Rostami K, Ghasemi A, Emami M, Fereidouni Z. Investigation of diabetes prevention behaviors among teachers of different level of education based on Pender model in selected educational centers in southwestern Iran, 2019. Revista Latinoamericana de Hipertensión. 2019;14(4):290-4. 